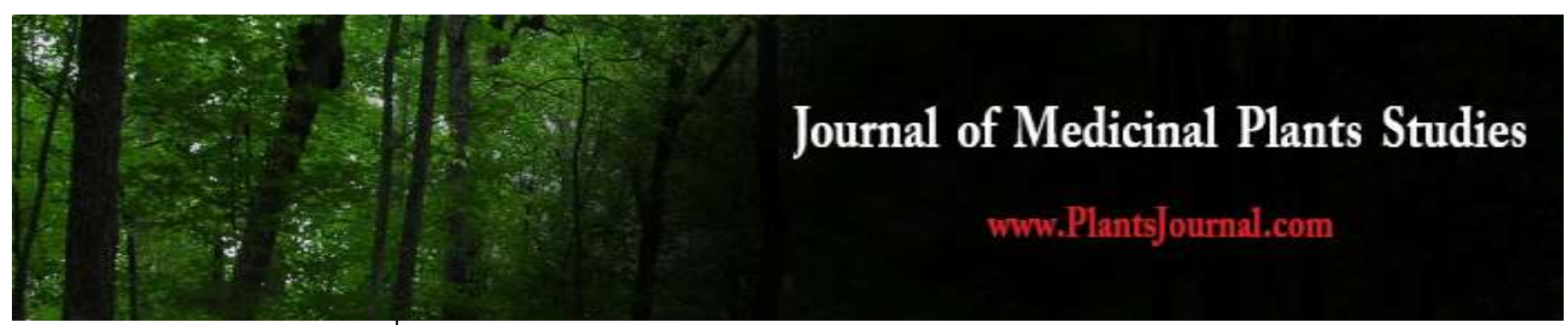

ISSN (E): 2320-3862

ISSN (P): 2394-0530

NAAS Rating: 3.53

www.plantsjournal.com

JMPS 2021; 9(1): 14-20

(C) 2021 JMPS

Received: $28-10-2020$

Accepted: 08-12-2020

Sanjana Bhagat

Department of Pharmaceutical

Sciences of Technology, Birla

Institute of Technology, Mesra,

Ranchi, Jharkhand, India

\section{Dhiraj Kumar}

Department of Pharmaceutical

Sciences of Technology, Birla

Institute of Technology, Mesra,

Ranchi, Jharkhand, India
Corresponding Author: Sanjana Bhagat

Department of Pharmaceutical

Sciences of Technology, Birla

Institute of Technology, Mesra,

Ranchi, Jharkhand, India

\section{A recepto-informatics study of the phytocompounds of Tabernaemontana divaricata (L.) having potential anticancer efficacy for breast cancer}

\section{Sanjana Bhagat and Dhiraj Kumar}

DOI: https://doi.org/10.22271/plants.2021.v9.i1a.1242

\section{Abstract}

Background: Breast cancer could be a serious global health concern causing the best mortality rate in females. Available synthetic medicine to treat breast cancer are marred by extreme toxicity problems and recommend some alternate route to handle the dreadful disease. The present study is an Insilco effort to identify the antitumor potential of Tabernaemontana divaricata plant metabolites.

Materials and Methods: The structure of the Human estrogen Receptor (HER), a possible target of breast cancer was selected as target molecules, retrieved from the protein data Bank (PDB) and therefore the structures of alkaloids compounds are collected from PubChem database. Molecular docking and drug similarity studies were performed for these alkaloids compounds to assess and analyze the antibreast cancer action.

Results: The detailed interaction studies of a few alkaloids (Coronaridine, Voacangine, Voacristine, Catharanthine, and Ibogamine) suggest that the compound could serve as probable lead molecules in drug development. All these five compounds also exhibited the highest binding affinity with human ER more significant than $8.7 \mathrm{Kcal} / \mathrm{mol}$ which is more affinity as compared to that of standard drugs Tamoxifen.

Conclusion: The results of this study is enforced to design novel anti-cancerous medicine within the coming future. The interaction studies of the standard drug with breast cancer markers serve as a tool to synthesize new compounds of desired effectiveness against the deadly disease.

Keywords: Human estrogen receptor, breast cancer, molecular docking, phytocompounds, ADME

\section{Introduction}

Breast cancer is one of the foremost leading causes of death in women across the world accounting for about $15 \%$ of all female cancer deaths in the United states ${ }^{[1]}$. Healthy breast cells and most carcinoma cells possess receptors for estrogen and progesterone circulating within the blood ${ }^{[2]}$. The binding of hormones with their individual receptors induces growth response within the type of signal cascade culminating in cell proliferation and growth. Moreover, both estrogen and progesterone perform following oncogenes and neoplasm suppressor genes leading to cancer progression ${ }^{[3]}$. Breast cancer is a type of cancer that start from breast tissue. Cancer may be a gathering of maladies that reason cells within the body to alter and develop out of control. Most types of cancer cells within the finish frame have a lump or mass referred to as a tumor and are named when the components of the body wherever the tumor begins. The larger a part of breast cancer begin within the parts of the breast tissue that comprises organs for milk production, known as lobules, and ducts that associate the lobules to the nipple ${ }^{[4-5]}$. Risk factors for making breast cancer incorporate being female, obesity, absence of exercise, drinking alcohol, hormone substitution treatment amid menopause, radiation, early age initially menstruation, having kids late or not within the least, older age, earlier history of breast cancer, and family history ${ }^{[6]}$.Tabernaemontana divaricata is usually called Chandani from the Apocynaceae family. The plant is an evergreen shrub growing to a height of six feet and located in all parts of India ${ }^{[1]}$. This species has been extensively investigated and a variety of chemical constituents like alkaloids, triterpenoids, steroids, flavonoids, phenylpropanoids and phenolic acids were isolated from leaves, roots and stems of the plant ${ }^{[7]}$. The Leaves, Stems, Barks, Roots and flowers are utilized in numerous Ayurvedic or Unani herbal preparations. 
At least 66 alkaloids like (Coronaridine, Voacangine, Ibogamine, Voaharine, Mehranine, Voaphylline, Harmine, Voacristine, Morin, Tubotaiwine, Stemmadenine, Vallesamine, Apparicine and Catharanthine) were extracted from $\mathrm{T}$. divaricata by many strategies like thin layer chromatography (TLC), high performance liquid chromatography (HPLC) and gas chromatography-mass spectrophotometry (GC-MS). It might be utilised as a rasayana to advance era, and typically to enhance assimilation, treat epilepsy, abdominal tumours, eye infections, fractures, fever, headache, inflammation, mania, oedema, leprosy, diarrhoea, and upgrade intellect ${ }^{[8]}$. Molecular docking could be a basic instrument within the amendment of recent prescriptions. Docking procedure grants portrayal, the direct of a test little molecule within the coupling site of the receptor target of interest. A productive docking strategy should have the power to adequately envision the native ligand representing the receptor limiting site and therefore the connected physical-compound submolecular affiliations [9-11]. The aim of this study was to screen out the effective bioactive alkaloids' compounds from tabernaemontana divaricata, which can be potential inhibitors of estrogen receptor alpha (ER- $\alpha)$ in future and should act as a drug which can be effective in preventing the breast cancer.

\section{Materials and Methods \\ Retrieval of atomic structure and analog preparation}

All the software used for the analysis is freely available for educational use. The PDB (www.rcsb.org) ${ }^{[12]}$ could be a worldwide repository for the process and distribution of $3 \mathrm{D}$ biological macromolecular structure information. The macromolecule structure of HER (PDB ID 3ERT) was downloaded from PDB.

\section{Drug targets}

A total of 14 alkaloids were identified from the "Tabernaemontana divaricata" literature search that showed inhibitory effects on breast cancer cells. The 3-D structure of Tamoxifen and other alkaloids' compounds i.e., Coronaridine, Voacangine, Ibogamine, Voaharine, Mehranine, Voaphylline, Harmine, Voacristine, Morin, Tubotaiwine, Stemmadenine, Vallesamine, Apparicine and Catharanthine were downloaded in sdf format using PubChem and converted to PDB format using Open Babel and further used for docking studies(Fig. $1)$.

\section{Molecular docking}

The present study was confined to human estrogen receptor, an anti-breast cancer drug (Tamoxifen, Toremifene and Raloxifene) and alkaloids' compounds i.e., Coronaridine, Voacangine, Ibogamine, Voaharine, Mehranine, Voaphylline, Harmine, Voacristine, Morin, Tubotaiwine, Stemmadenine, Vallesamine, Apparicine and Catharanthine. Molecular docking was performed to calculate the extent of drugreceptor binding energy. The docking experiments were performed using AutoDock1.5.6 (The Scripps research Institute, www.scripps.edu, help from AutoDock Tools (ADT), an extra program that permits the user to correlate with Auto Dock from a Graphic computer programme (GUI). Auto Dock could be a set of automated docking tools meant to forecast however small molecules/ligands, like substrates or drug candidates, bind to a receptor/protein of better-known 3D arrangement. For its input and output, it uses the PDBQT molecular structure file format. PDBQT files are often generated (interactively or in batch mode) and viewed as victimisation MGL tools. BIOVIA Discovery Studio visualizer has been chosen for the analysis of docking results
[13].

\section{Preparation of the ligand and macromolecule files for Auto Dock}

The PDB files obtained from the world-Wide internet repository are usually removed from perfect for docking study and present with potential issues like missing hydrogen atoms, multiple molecules, added waters, and related problems. victimisation the GUI of ADT, files were prepared. Auto Dock would like receptor and ligand representations in a specific PDBQT format that may be a changed protein data bank format containing atomic charges, atom type definitions and for ligands all the topological information ${ }^{[14]}$. These file preparations are administered by the plugin using scripts from the Auto Dock Tools package.

\section{The Macromolecule files}

The downloaded PDB file of HER (PDB ID 3ERT) was first read in ADT, added waters removed and non-polar hydrogen were added. Compute gasteiger charges were added. Finally, the file was saved with. PDBQT extension.

\section{The Ligand File}

In a parallel method, the ligand files were examined in ADT, all hydrogen added, charges added, and non-polar hydrogen incorporated and saved with PDBQT extension. ADT then automatically determined the most effective root. The ligand files were then saved with. PDBQT extension.

\section{The Grid Parameter File}

Auto Dock uses 3D rectangular boxes (Grid box) for defining the binding site. In the plugin, the box centre will be defined by providing specific coordinates (Grid parameter file). The grid volume was large enough to permit the ligand to rotate freely, even with its most absolutely extended conformation. The grid parameter involves drawing a zone consisting of $\mathrm{X}$, $\mathrm{Y}$, and $\mathrm{z}$-axis in $3 \mathrm{D}$ to hide the entire molecule and permits for ligand binding. The parameters used for the docking process were as follows: Centre $\mathrm{x}=30.282$, centre $\mathrm{y}=-1.913$, centre $\mathrm{z}=24.207$, size $\mathrm{x}=40$, size $\mathrm{y}=40$, size $\mathrm{z}=40$, exhaustiveness $=10$. The parameters needed to make such a grid were held on within the Grid Parameter File with. gpf extension.

\section{The Docking Parameter File}

The docking parameter file, that instructs Auto Dock regarding the ligand to move, the map files to use, and alternative properties defined for the ligand was created. Auto Dock's search strategies include the Genetic algorithmic program (GA), local search (LS), and therefore the hybrid genetic algorithmic program with local search (GALS).

\section{Running Auto dock}

Finally, the Auto dock program was run and resultant files (in PDBQT format) therefore developed were checked in BIOVIA Discovery Studio visualizer for its 3D orientations and therefore the binding energies of the docked ligandprotein complexes were observed.

\section{Analysis and visualization of the docked poses complex} After docking, poses with the highest negative binding free energy $(\mathrm{kcal} / \mathrm{mol})$ were chosen because the best pose for corresponding ligand binding in case of Auto Dock. The best predicted poses were visualized and analyzed by BIOVIA Discovery Studio visualizer to demonstrate ligand-protein 
interactions thoroughly. The inhibition constant (Ki) for every ligand was calculated using the binding free energy.

\section{ADMET calculation}

ADMET identification is a vital indicator in deciding the efficacy and safety of a drug compound to bring it into commercialization. Due to the time and cost-effectiveness of experimental analysis of ADMET properties, computational ways became a practicable alternative so far, that might break through the 'bottleneck' within the high-throughput drug discovery process. Hence, ADMET properties of the chosen compounds were predicted by Swiss-ADME online database. Various toxicity parameters, metabolizing enzyme interactions, and absorption parameters were evaluated for the screened compounds, and therefore the results are given in [Table 2].

\section{BBB}

$\mathrm{BBB}$ is one of the most essential parameters of the ADMET study. In the cardiovascular system, BBB could be a physical barrier that prohibits several substances from traveling into the central nervous system. drugs when interacting with molecular targets within the central nervous system, should cross the BBB to be used as therapeutic agents. On the other hand, medications recommended for peripheral targets, low or no BBB penetration might be needed to avoid side effects of the central nervous system.

\section{Human Intestinal Absorption level (HIA)}

For oral drug development, the prediction of HIA may be an important concern for choice as a candidate drug molecule. Drugs that are largely absorbed by the intestine and later excreted are thought as helpful for cancer treatment.

\section{Solubility level}

Other considerations within the drug development industry face are their solubility in associate aqueous medium. The potent drug should be miscible to be effective within the treatment of disease.

\section{Plasma protein binding (PPB)}

It is widely accepted the actual fact that only free drugs will cross membranes and bind to the proposed molecular target (Smith DA., et al. 2001). Drugs will bind an excess of cells and proteins present within the blood, together with blood cell, WBC, platelets, albumins, glycoproteins, lipoproteins and globulins.

\section{Polar surface area (PSA)}

PSA of the molecule will be defined as the area of its van der Waal's surface that arises from the oxygen, nitrogen, or hydrogen atoms connected to oxygen or nitrogen atoms. psa within the vary of 80-100 ( $\mathrm{\AA} 2)$ is advisable for drug-protein interaction (Clark de, 1999).

\section{Result and Discussion}

There is a robust correlation between levels of estrogen with the chance of breast cancer. The estrogen present in high concentration within the breast cancer cells binds to ER to stimulate to indicate an impact like genesis, cell caspasemediated cell death and malignant development. Two forms of ER present within the breast cancer cell are estrogen Receptor alpha (ER- $\alpha)$ and estrogen Receptor Beta (ER- $\beta$ ). Uterus, vagina, mammary gland and pituitary gland show the most expression of ER- $\alpha$. Abnormal expression of ER- $\alpha$ plays a major role in breast cancer development affecting around 70 th of the first breast cancer population ${ }^{[18-20]}$. ER- $\alpha$ plays a vital role in transcription of DNA necessary for gland development; besides, it additionally acts as an important issue for the downstream signaling pathway ${ }^{[21]}$. It additionally regulates cell proliferation and differentiation through the paracrine method. Thus, ER inhibition offers a sensible approach to the prevention and treatment of breast cancer ${ }^{[22]}$. Some of the potent antineoplastic drugs that are often used like tamoxifen, Raloxifene and Toremifene either interfere with estrogen production or estrogen action [23]. Unfortunately, these medicines are related to many toxic manifestations, together with blood clotting, stroke, cancer of uterine and cataracts ${ }^{[24,25]}$. Thus, there's a continuing need to search and establish novel drugs of phytochemical origin with less toxic effects.

HER- $\alpha$ has been exploited as a first therapeutic target for breast cancer. The 3D structure of HER- $\alpha$ retrieved from the PDB (PDB ID: 3ERT) determined by X-ray crystallography at a resolution of $1.60(\AA)$ was visualized in Discovery Studio. The HER- $\alpha$ consists of 595 amino acids and contains 3 domains: a modulating N-terminal domain, a DNA-binding domain and a C-terminal ligand-binding domain (LBD). The $\mathrm{N}$-terminal modulating domain, additionally called the $\mathrm{A} / \mathrm{B}$ or AF-1 domain contains a ligand-independent transactivation perform. The C-terminus contains a ligand-dependent transactivation domain, additionally called $\mathrm{E} / \mathrm{F}$ or $\mathrm{AF}-2$ domain that overlaps with the ligand-binding domain. The $\mathrm{C}$ terminal region possesses a DNA binding domain and is very preserved (96\%) as compared to ERs. AF-1 and AF-2 activate transcription severally and synergistically and act during a promoter- and cell specific manner. AF-1 looks to produce a big transactivation performed in differentiated cells.

Molecular docking studies of 14 identified alkaloids compounds were carried out to calculate the free binding energy using Autodock (Tab. 1B). To identify the plausible binding modes, detailed molecular docking analysis of potent compounds against estrogen receptors were also performed. The binding orientation of potent compounds Coronaridine, Voacangine, Voacristine, Catharanthine, Ibogamine and cocrystal ligand within the active site of target enzyme is shown in (fig.2). The putative binding mode of Coronaridine, Voacangine, Voacristine, Catharanthine, Ibogamine within the active site of Estrogen receptor (fig.3). Analyzing the key interactions of Coronaridine, Voacangine, Voacristine, Catharanthine, Ibogamine in active site of Estrogen receptors revealed that compounds were surrounded by aromatic ring containing amino acid residue that was THR347, PHE404, LEU391, HIS524, GLY521, LEU525 and His440 (Table 1A $\&$ Fig 3). Further analysis of docking results showed that five alkaloids are stacked well within the grove between LEU525 and LEU346 amino acid residues. Compound Voacangine, Voacristine formed only one H-bond interaction with the sixmembered ring of the amino acid residue MET 421 and ARG 394. Thus, each H-bond and hydrophobic interactions contribute to the binding affinity and stability of the complex. 
Table 1A: Showing interacting amino acids of a few Alkaloids/Tamoxifen

\begin{tabular}{|c|c|c|c|c|}
\hline $\begin{array}{l}\text { S. } \\
\text { No }\end{array}$ & Ligand Molecules & $\begin{array}{c}\text { Molecular } \\
\text { formula }\end{array}$ & $\begin{array}{c}\text { Binding energy } \\
\text { (Kcal/mol) }\end{array}$ & Interacting Amino Acids \\
\hline 1 & Coronaridine & $\mathrm{C}_{21} \mathrm{H}_{26} \mathrm{~N}_{2} \mathrm{O}_{2}$ & -9.13 & $\begin{array}{l}\text { THR347, LEU384, MET421, LEU349, PHE404, LEU387, ILE424, } \\
\text { LEU525, LEU391 }\end{array}$ \\
\hline 2 & Voacangine & $\mathrm{C}_{22} \mathrm{H}_{28} \mathrm{~N}_{2} \mathrm{O}_{3}$ & -9.01 & $\begin{array}{l}\text { LEU387, MET388, MET421, LEU384, GLY521, ALA350, GLU353, } \\
\text { LEU391, ILE424 }\end{array}$ \\
\hline 3 & Ibogamine & $\mathrm{C}_{19} \mathrm{H}_{24} \mathrm{~N}_{2}$ & -8.88 & $\begin{array}{l}\text { MET421, LEU346, LEU384, HIS524, ILE424, ALA350, LEU387, LEU391, } \\
\text { PHE404, LEU387 }\end{array}$ \\
\hline 4 & Voacristine & $\mathrm{C}_{22} \mathrm{H}_{28} \mathrm{~N}_{2} \mathrm{O}_{4}$ & -9.32 & $\begin{array}{c}\text { TRP383, LEU525, LEU387, MET388, GLY521, HIS524, ARG394, } \\
\text { LEU349, MET343, ILE424 }\end{array}$ \\
\hline 5 & Catharanthine & $\mathrm{C}_{21} \mathrm{H}_{24} \mathrm{~N}_{2} \mathrm{O}_{2}$ & -9.26 & $\begin{array}{c}\text { MET343, ILE424, HIS524, LEU384, LEU346, LEU391, LEU525, MET421, } \\
\text { ALA350, LEU349, GLY521 }\end{array}$ \\
\hline 6 & Tamoxifen & $\mathrm{C}_{26} \mathrm{H}_{29} \mathrm{NO}$ & -6.8 & ALA350, ILE404, HIS394, GLY353, MET347, LEU346, LEU349, TRP384, \\
\hline
\end{tabular}

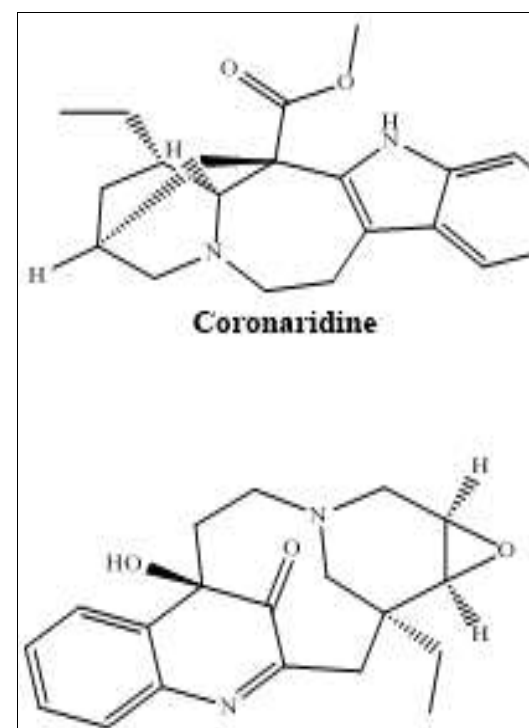

Voaharine<smiles>COc1ccc2c(c1)[nH]c1c(C)nccc12</smiles>

Harmine<smiles>CCC1C2=C(C(=O)OC)C3C1CC1(CCN3C1)c1ccccc1N2</smiles>

Tubotaiwin

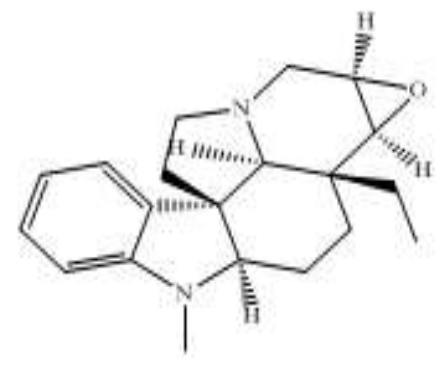

Mehranine

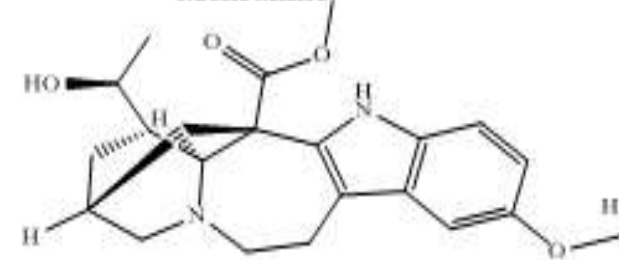

Voacristine

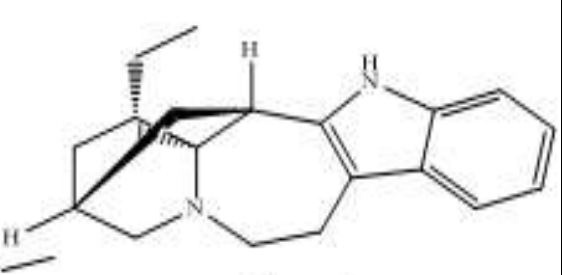

Ibogamine

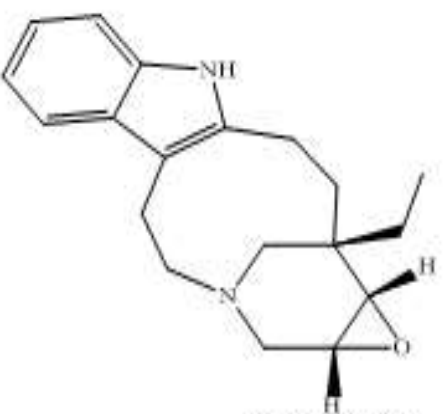<smiles>O=c1c(O)c(-c2ccc(O)cc2Cl)oc2cc(O)cc(O)c12</smiles>

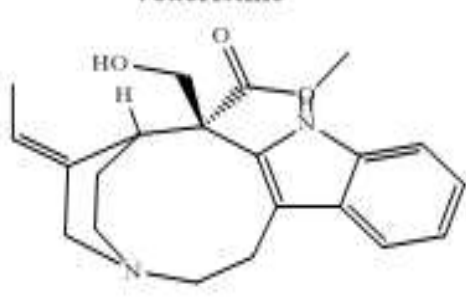

Stemmadenine
Morin

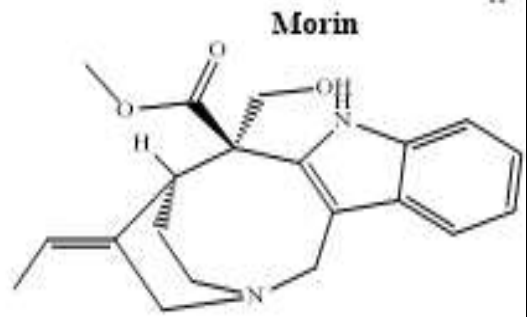

Vallesamine

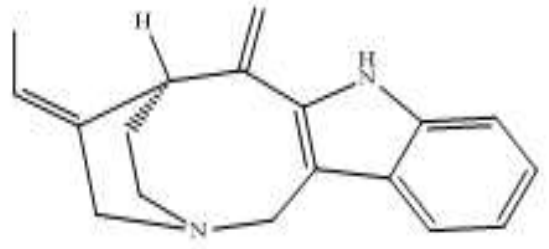

Apparicine

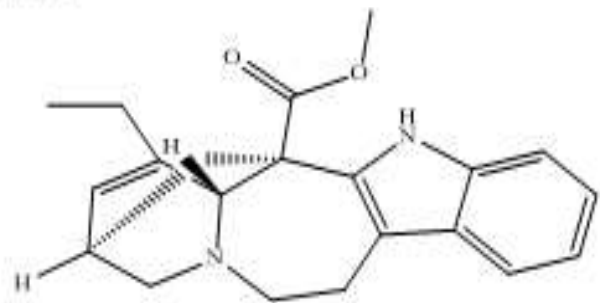

Catharanthine

Fig 1: Chemical structure of phytochemicals of Tabernaemontana divaricata used in molecular docking as a ligand. 


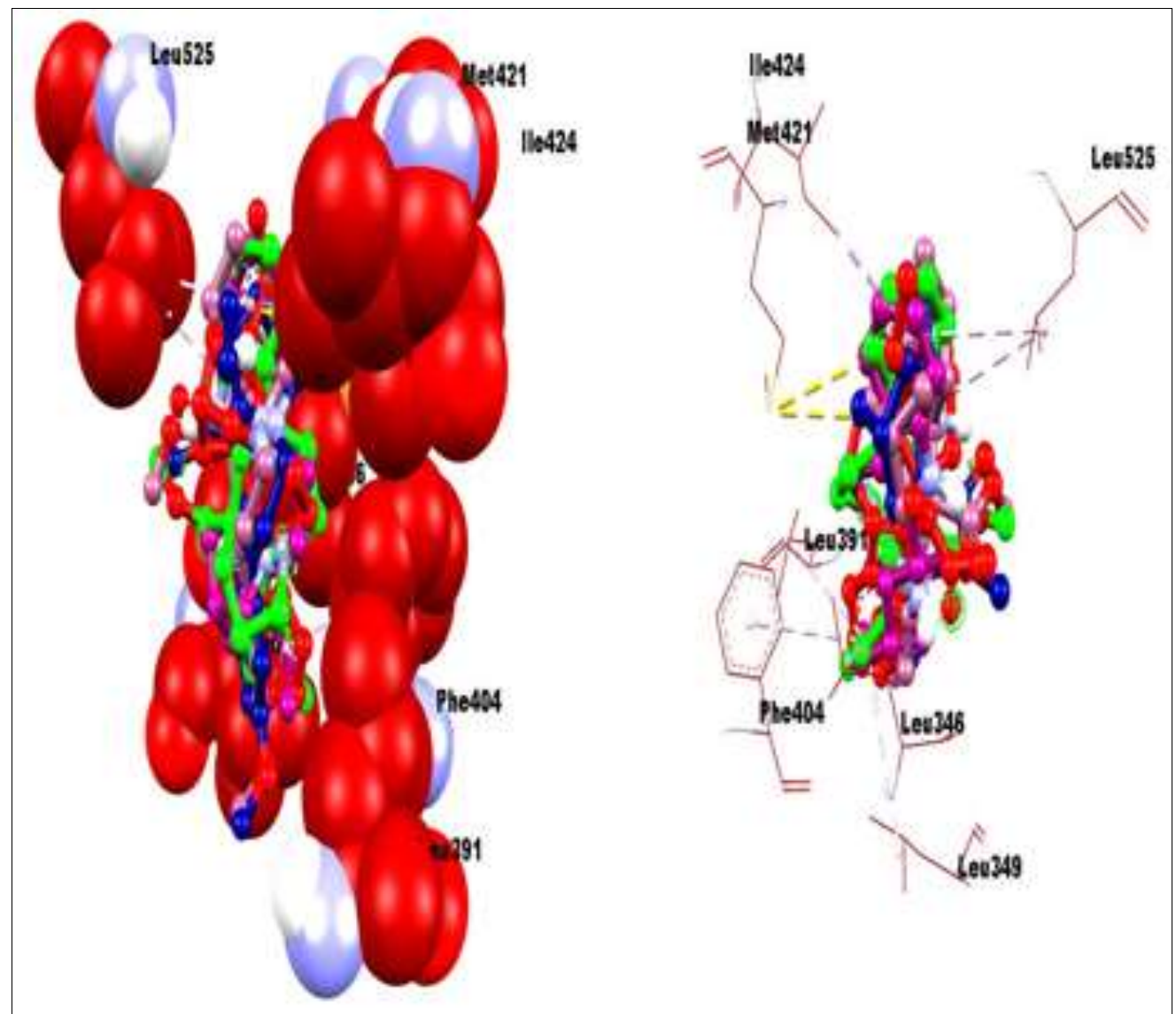

Fig 2: Putative binding orientation of Coronaridine, Voacangine, Voacristine, Catharanthine, Ibogamine and co-crystal ligand within the active pocket of Estrogen Receptor (PDB ID: 3ERT)
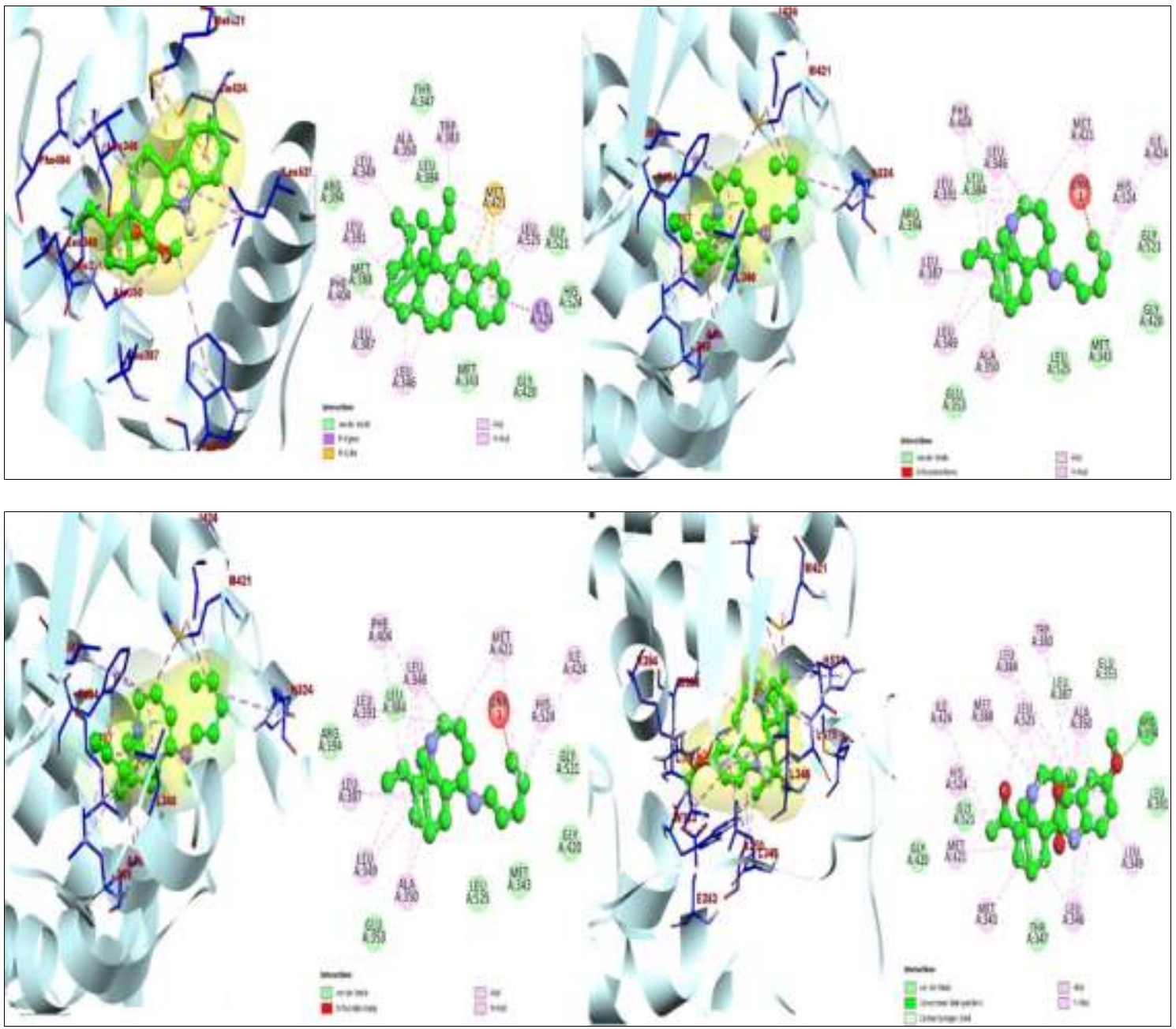


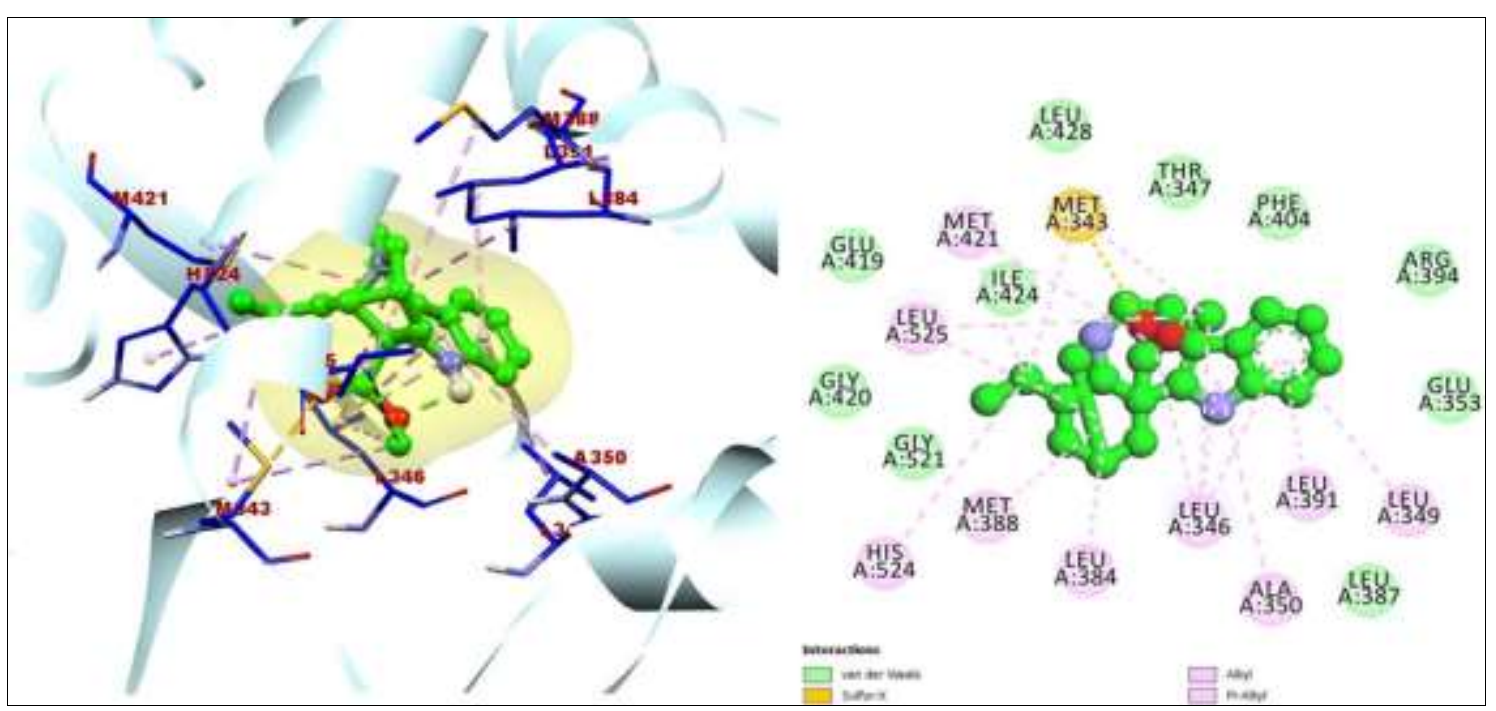

Fig 3: 3D \& 2D binding interactions of Coronaridine, Voacangine, Voacristine, Catharanthine, Ibogamine within the Estrogen Receptor (PDB ID: 3ERT) binding pocket

Table 1B: Binding energy of different alkaloids and drugs (Tamoxifen) with human estrogen receptor.

\begin{tabular}{|c|c|c|c|c|}
\hline S. No. & Compound/Drugs & Mol. Formula & Binding Energy (Kcal/mol) & Inhibition Constant(kI) \\
\hline 1 & Coronaridine & $\mathrm{C}_{21} \mathrm{H}_{26} \mathrm{~N}_{2} \mathrm{O}_{2}$ & -9.13 & $204.75 \mathrm{~nm}$ \\
\hline 2 & Voacangine & $\mathrm{C}_{22} \mathrm{H}_{28} \mathrm{~N}_{2} \mathrm{O}_{3}$ & -9.01 & $246.98 \mathrm{~nm}$ \\
\hline 3 & Ibogamine & $\mathrm{C}_{19} \mathrm{H}_{24} \mathrm{~N}_{2}$ & -8.88 & $308.31 \mathrm{~nm}$ \\
\hline 5 & Voaharine & $\mathrm{C}_{19} \mathrm{H}_{22} \mathrm{~N}_{2} \mathrm{O}_{3}$ & -8.41 & $682.83 \mathrm{~nm}$ \\
\hline 6 & Mehranine & $\mathrm{C}_{20} \mathrm{H}_{26} \mathrm{~N}_{2} \mathrm{O}$ & -8.8 & $354.62 \mathrm{~nm}$ \\
\hline 7 & Voaphylline & $\mathrm{C}_{19} \mathrm{H}_{24} \mathrm{~N}_{2} \mathrm{O}$ & -8.85 & $324.31 \mathrm{~nm}$ \\
\hline 8 & Harmine & $\mathrm{C}_{13} \mathrm{H}_{12} \mathrm{~N}_{2} \mathrm{O}$ & -6.21 & $28.1 \mathrm{um}$ \\
\hline 9 & Voacristine & $\mathrm{C}_{22} \mathrm{H}_{28} \mathrm{~N}_{2} \mathrm{O}_{4}$ & -9.32 & $147.32 \mathrm{~nm}$ \\
\hline 10 & Morin & $\mathrm{C}_{15} \mathrm{H}_{10} \mathrm{O}_{7}$ & -7.31 & $4.37 \mathrm{um}$ \\
\hline 11 & Tubotaiwine & $\mathrm{C}_{20} \mathrm{H}_{24} \mathrm{~N}_{2} \mathrm{O}_{2}$ & -8.76 & $382.12 \mathrm{nM}$ \\
\hline 12 & Vallesamine & $\mathrm{C}_{20} \mathrm{H}_{24} \mathrm{~N}_{2} \mathrm{O}_{3}$ & -7.77 & $2.01 \mathrm{uM}$ \\
\hline 13 & Apparicine & $\mathrm{C}_{18} \mathrm{H}_{20} \mathrm{~N}_{2}$ & -8.08 & $1.19 \mathrm{uM}$ \\
\hline 14 & Catharanthine & $\mathrm{C}_{21} \mathrm{H}_{24} \mathrm{~N}_{2} \mathrm{O}_{2}$ & -8.24 & $917.0 \mathrm{nM}$ \\
\hline 15 & Tamoxifen & $\mathrm{C}_{26} \mathrm{H}_{29} \mathrm{NO}$ & -9.26 & $161.89 \mathrm{nM}$ \\
\hline
\end{tabular}

\section{ADME profile of identified alkaloids compounds}

To evaluate the drug-like properties of all identified alkaloids compounds, a series of computational filters, as well as filters for $\operatorname{cog} \mathrm{P}$ and predicted solubility were accustomed to choose the correct compounds from their library. In general, compounds adhered to Lipinski's rules five (i.e., molecular mass <500, H-bond donors <5, H-bond acceptors <10, and $\log \mathrm{P}<5)$ were proceed for their catalytic potentials. In-silico analysis of ADME profiles for these compounds were done beside calculation of free binding energies and different ADME properties. The targeted properties, i.e., $\log \mathrm{P}(\mathrm{o} / \mathrm{w})$ (octanol-water partition coefficient), $\mathrm{HBDH}$ (number of hydrogen bond donor atom), HBAH, (number of hydrogen bond acceptor atom and TPSA (topological polar surface area) were with success evaluated (Table 2). Among all these 14 alkaloids compounds only 5 compounds Coronaridine, Voacangine, Voacristine, Catharanthine, Ibogamine have $\log \mathrm{P}$ $<5$, which is a measure of lipophilicity.

Table 2: ADMET prediction with the help of Swiss-ADME

\begin{tabular}{|c|c|c|c|c|c|c|c|c|c|}
\hline \multicolumn{10}{|c|}{ ADMET } \\
\hline S. No & Name of compound & BBB & HIA & Sol. & Molecular weight (g/mol) & PSA $\left(\AA^{2}\right)$ & SlogP & Lipdruglike & NoR \\
\hline 1 & Coronaridine & Yes & High & 4.24 & 338.44 & 45.33 & 3.31 & 0 & 3 \\
\hline 2 & Voacangine & Yes & High & 4.34 & 368.47 & 54.56 & 3.30 & 0 & 4 \\
\hline 3 & Ibogamine & Yes & High & 4.05 & 280.41 & 19.03 & 3.58 & 0 & 1 \\
\hline 4 & Voaharine & No & High & 1.78 & 326.39 & 65.43 & 1.70 & 0 & 1 \\
\hline 5 & Mehranine & Yes & High & 3.28 & 310.43 & 19.01 & 2.86 & 0 & 1 \\
\hline
\end{tabular}




\begin{tabular}{|c|c|c|c|c|c|c|c|c|c|}
\hline 6 & Voaphylline & Yes & High & 3.66 & 296.41 & 31.56 & 3.15 & 0 & 1 \\
\hline 7 & Harmine & Yes & High & 4.23 & 212.25 & 37.91 & 2.78 & 0 & 1 \\
\hline 8 & Voacristine & Yes & High & 3.57 & 384.47 & 74.79 & 2.47 & 0 & 4 \\
\hline 9 & Morin & No & High & 3.91 & 302.24 & 131.36 & 1.20 & 0 & 1 \\
\hline 10 & Tubotaiwine & Yes & High & 3.60 & 324.42 & 41.57 & 2.76 & 0 & 3 \\
\hline 11 & Stemmadenine & Yes & High & 2.80 & 354.44 & 65.56 & 2.50 & 0 & 3 \\
\hline 12 & Vallesamine & Yes & High & 2.32 & 340.42 & 65.56 & 2.05 & 0 & 3 \\
\hline 13 & Apparicine & Yes & High & 2.79 & 264.36 & 19.03 & 3.30 & 0 & 0 \\
\hline 14 & Catharanthine & Yes & High & 3.41 & 336.43 & 45.33 & 3.14 & 0 & 3 \\
\hline
\end{tabular}

\section{Conclusion}

The type and number of interactions between macromolecule and its ligand play a vital role within the drug design based on structure in the current work, computational approaches are exploited to identify the mechanism of interactions and binding affinity between HER and few phytochemicals. Our data suggested that at least some of the Alkaloids of Tabernaemontana divaricata (Coronaridine, Voacangine, Voacristine, Catharanthine, and Ibogamine) possess a high binding affinity for breast cancer receptors than the wellestablished drugs available in the market. The present analysis also shows that Leu525, Leu346, Leu391, Phe404 and Leu525 are the most critical residues of potential drug targets. Reported Phyto-compounds from this study can be exploited because the model for planning therapeutic lead compounds that could result in wide reductions within the therapeutics development period. From ADMET study of identified alkaloids compounds indicated that it could be zero violation of Lipinski Rule 5. This study wants experimental validation and clinical trials to determine phytochemical property as a more potent drug for the management of various types of cancers generally and breast cancer especially.

\section{References}

1. Hilakivi-Clarke L, Wang C, Kalil M, Riggins R, Pestell R. Nutritional modulation of the cell cycle and breast cancer. Endocrine-Related Cancer, [online] 2004;11(4):pp.603-622. Available at: <http://10.1677/erc.1.00665>.

2. Espeland M, Shumaker S, Limacher M, Rapp S, Bevers $\mathrm{T}$, Barad D et al., Relative Effects of Tamoxifen, Raloxifene, and Conjugated Equine Estrogens on Cognition. Journal of Women's Health, [online] 2010;19(3):371-379. Available at: <http://10.1089/jwh.2009.1605>.

3. Espeland M, Shumaker S, Limacher M, Rapp S, Bevers $\mathrm{T}$, Barad D et al., Relative Effects of Tamoxifen, Raloxifene, and Conjugated Equine Estrogens on Cognition. Journal of Women's Health, [online] 2010;19(3):371-379. Available at: <http://10.1089/jwh.2009.1605>

4. Helgeson VS, Cohen S, Schulz R, Yasko J. Group support interventions for women with breast cancer: who benefits from what? Heal Psychol 2000;19(2):107.

5. Padmaja M, Hemalatha K. Anti-oxidant and free radical scavenging activity of Tabernaemontana divaricata. J Pharm res 2011;4(9):2981-2984.

6. Pawelka KH, Stoeckigt J. Indole alkaloids from cell suspension cultures of Tabernaemontana divaricata and Tabernaemontana iboga. Plant Cell Rep 1983;2(2):105107.

7. Ghani A. Medicinal Plants of Bangla-desh; Chemical constituents and uses. Asiatic Society of Bangladesh, Dhaka 2003;381;1-16.

8. Md. Alamgir H, Md. Towhidul Islam T, Aloke Soumya S, Md Salman F, Whaheduzzaman, Md Mostafa M et al.
Insilco Docking Studies of Some Isolated Selected Compounds of Phoenix sylvestris (L.) Against Thrombosis. Biomed J Sci \& Tech Res 2019;20(2):BJSTR. MS.ID.003426.

9. Lu S-H, Wu JW, Liu H-L. The discovery of potential acetylcholinesterase inhibitors: a combination of pharmacophore modeling, virtual screening, and molecular docking studies. J Biomed Sci 2011;18(1):8.

10. Shanta A, Nazim U, Kazi Zahra M, Tarannur Kabir N, Fayejun N, Shermin A. In Silico Molecular Docking Approch of Some Selected Isolated Phytochemicals from Phyllanthus Emblic Against Breast Cancer. Biomed J SciTech Res 10(2)-2018. BJSTR. MS.ID.001917. DOI: 10.26717/ BJSTR.2018.10.001917.

11. The Protein Data bank, Helen Berman et al. Oxford Journal, Nucleic acid Research 1999;28.1:235-242.

12. Mohd Ahmar Rauf et al. Ligand Docking and binding site analysis with Pymol \& autodock. IJBAS 2015;4.2:168-177.

13. Berman HM, Bhat TN, Bourne PE, Feng Z, Gilliland G, Weissig H. The Protein Data Bank and the challenge of structural genomics. Nat Struct Biol. 2000;7:957-9. Doi: 10.1038/80734. PMID: 11103999. 